\title{
Palatal tremor in relation to brainstem tumour involvement
}

\author{
Joana Marques, ${ }^{1}$ Hipólito Nzwalo, ${ }^{2}$ Ana Azevedo, ${ }^{1}$ Duarte Salgado ${ }^{1}$
}

${ }^{1}$ Department of Neurology, Instituto Português de Oncologia de Lisboa, Francisco Gentil, Lisboa, Portugal ${ }^{2}$ Department of Neurology, Hospital de Faro, Faro, Portugal

\section{Correspondence to} Dr Hipólito Nzwalo, nzwalo@gmail.com

\section{DESCRIPTION}

A 32-year-old woman with idiopathic congenital moderate mental retardation was being followed because of presumed primary central nervous system lymphoma (previous clinical evolution and investigation summarised in table 1)

She was admitted for clinical re-evaluation because of motor and cognitive deterioration. She was bedridden, tetraparetic, with severe cognitive impairment preventing any verbal communication, apart from elementary responses. During the first week of hospitalisation she developed persistent elementary vocal tics and swallowing disturbance, often showing facial signs of discomfort. Oropharyngeal examination revealed the presence of continuous rhythmic movement of the soft palate typical of palatal tremor (video 1) which was also present during sleep. No repetitive audible clicks were noticed. Brain magnetic resonance disclosed the presence of lesions involving the dorsal midbrain tegmentum and periaqueductal area without hypertrophy of the inferior olive (figures 1 and 2). Baclofen was introduced with slight symptomatic relief. Palatal tremor, also called palatal myoclonus,

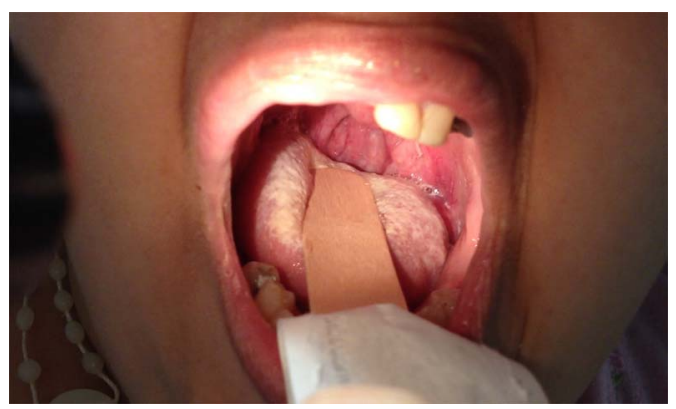

Video 1 Continuous rhythmic movement of the soft palate.

is a rare movement disorder characterised by brief, rhythmic involuntary movements of the soft palate. It is presumably caused by dysfunction (essential palatal tremor) or a lesion (symptomatic palatal tremor), involving the Guillain-Mollaret triangle also known as 'myoclonic triangle' (dentate nucleus, red nucleus, inferior olivary nucleus and central tegmental tract). Brainstem or cerebellar disorders such as stroke, demyelinating diseases,

Table 1 Previous clinical evolution and investigation

\begin{tabular}{|c|c|c|c|c|}
\hline Year & Clinical and imagiological findings & Investigation & $\begin{array}{l}\text { Treatment/ } \\
\text { evolution }\end{array}$ & $\begin{array}{l}\text { Presumed } \\
\text { diagnosis }\end{array}$ \\
\hline 2000 & $\begin{array}{l}\text { Somnolence, progressive right-sided } \\
\text { hemiparesis brain magnetic resonance: } \\
\text { left-sided hypointense on T2-weighted } \\
\text { with homogeneous } \\
\text { gadolinium-enhancing } \\
\text { lenticulo-thalamo-capsular lesion } \\
\text { (tumour? inflammatory?) }\end{array}$ & $\begin{array}{l}\text { Negative extensive blood }{ }^{*} \text { and } \\
\text { CSF** }^{*} \text { testing; normal EEG; biopsy } \\
\text { postponed : deep location of the } \\
\text { lesions, disappearance with } \\
\text { corticotherapy }\end{array}$ & $\begin{array}{l}\text { Corticotherapy/ } \\
\text { clinical and } \\
\text { radiological } \\
\text { remission }\end{array}$ & $\begin{array}{l}\text { Primary CNS*** } \\
\text { vasculitis? } \\
\text { Primary CNS } \\
\text { lymphoma? }\end{array}$ \\
\hline $\begin{array}{l}2000 \\
\text { (3 weeks } \\
\text { later) }\end{array}$ & $\begin{array}{l}\text { Right-sided central facial paresis, spastic } \\
\text { paretic gait resurgence of prior lesion } \\
\text { brain magnetic resonance }\end{array}$ & $\begin{array}{l}\text { Negative extensive blood and CSF } \\
\text { testing; normal EEG; HLA typing: } \\
\text { A24; B07, DRB1 11:04, 11:07; DQB1 } \\
\text { 03:01, 03:03 }\end{array}$ & $\begin{array}{l}\text { Corticotherapy/ } \\
\text { partial clinical and } \\
\text { radiological } \\
\text { remission }\end{array}$ & $\begin{array}{l}\text { Primary CNS } \\
\text { vasculitis? }\end{array}$ \\
\hline 2011 & $\begin{array}{l}\text { Headache, confusional state, residual } \\
\text { right crural paresis brain magnetic } \\
\text { resonance: multiple nodular hypointense } \\
\text { on T2-weighted with homogeneous T1 } \\
\text { gadolinium-enhancing supratentorial } \\
\text { lesions }\end{array}$ & $\begin{array}{l}\text { Inconclusive biopsy (encephalitis? } \\
\text { lymphoma?): presence of reactive } \\
\text { astrocytes and microgliosis, } \\
\text { perivascular mononuclear infiltrates; } \\
\text { atypical T and B lymphocytes on } \\
\text { immunohistochemical staining- } \\
\text { negative extensive blood and CSF } \\
\text { investigation; normal EEG }\end{array}$ & $\begin{array}{l}\text { Corticotherapy/ } \\
\text { clinical and } \\
\text { radiological } \\
\text { remission }\end{array}$ & $\begin{array}{l}\text { Primary CNS } \\
\text { lymphoma? }\end{array}$ \\
\hline 2013 & $\begin{array}{l}\text { Tetraparesis, worsening of the } \\
\text { pre-existing cognitive impairment brain } \\
\text { magnetic resonance: hypointense on } \\
\text { T2-weighted a with } \mathrm{T1} \\
\text { gadolinium-enhancing lesions in the } \\
\text { dorsal midbrain tegmentum and } \\
\text { periaqueductal area }\end{array}$ & $\begin{array}{l}\text { Negative extensive blood and CSF } \\
\text { testing; normal EEG }\end{array}$ & Corticotherapy & $\begin{array}{l}\text { Primary CNS } \\
\text { lymphoma? }\end{array}$ \\
\hline
\end{tabular}

To cite: Marques $J$, Nzwalo H, Azevedo A, et al. BMJ Case Rep Published online: [please include Day Month Year] doi:10.1136/ bcr-2013-009438 
Figure 1 Brain MRI showing lesions involving the dorsal midbrain tegmentum and periaqueductal area in axial fluid-attenuated inversion recovery $(A)$ and sagital $T 1$ with gadolinium (B) weighted images.

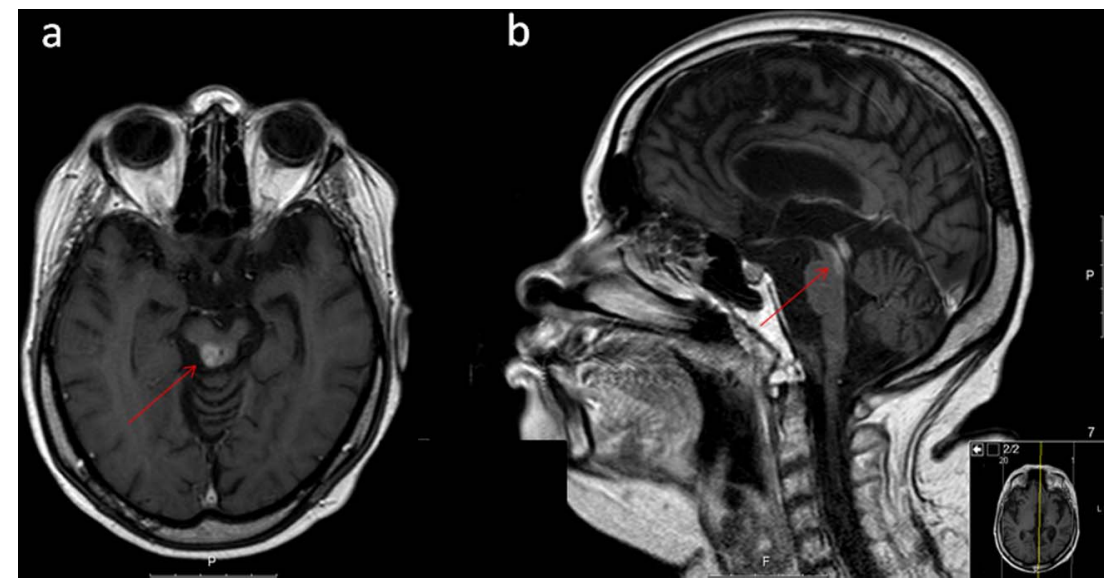

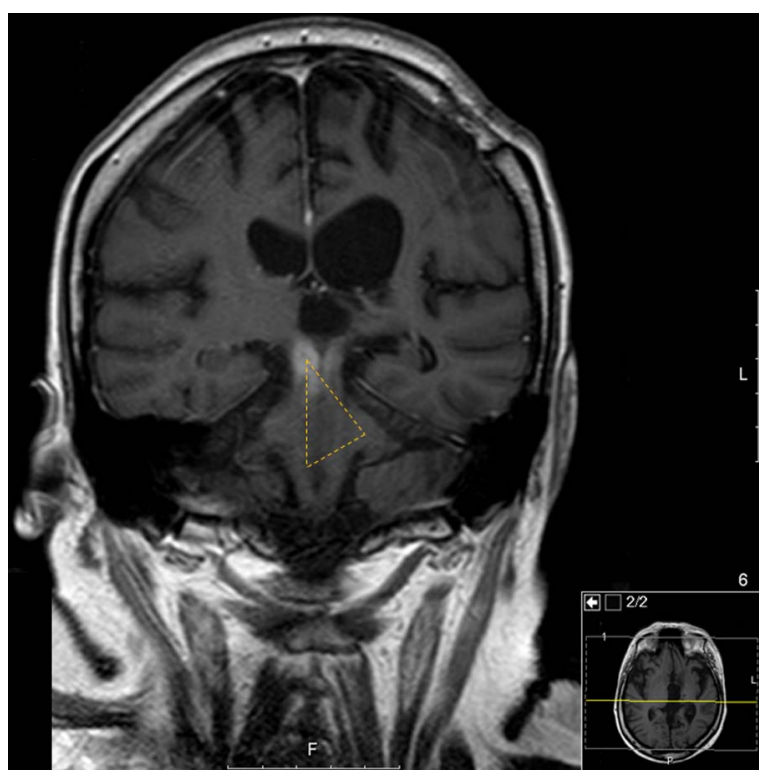

Figure 2 Lesion within Guillain Mollaret triangle (yellow triangle) on coronal $\mathrm{T} 1$ with gadolinum.

trauma and tumours are often identified. ${ }^{1}$ There is no established treatment for palatal tremor. Palatal botulinum toxin injections, and other drugs such as clonazepam, flunarizine, baclofen or sumatriptan are used, but these interventions are often unsuccessful. ${ }^{2} 3$

\section{Learning points}

- Palatal tremor is a rare movement disorder; when symptomatic (secondary) is usually described in association with lesions involving the Guillain-Mollaret triangle.

- Brain magnetic resonance is mandatory to identify an underlying lesion, particularly in cases of central nervous system tumours.

Contributors HN designed the study. JM wrote the manuscript; AA collected the data and drafted the manuscript; DS wrote and revised the manuscript. All authors read and approved the final manuscript.

Competing interests None.

Patient consent Obtained.

Provenance and peer review Not commissioned; externally peer reviewed.

\section{REFERENCES}

1 Deuschl G, Mischke G, Schenck E, et al. Symptomatic and essential rhythmic palatal myoclonus. Brain 1990;113:1645-72.

2 Penney SE, Bruce IA, Saeed SR. Botulinum toxin is effective and safe for palatal tremor: a report of five cases and a review of the literature. $J$ Neurol 2006:253:857-60.

3 Campistol-Plana J, Majumdar A, Fernández-Alvarez E. Palatal tremor in childhood: clinical and therapeutic considerations. Dev Med Child Neurol 2006:48:982-4.

Copyright 2013 BMJ Publishing Group. All rights reserved. For permission to reuse any of this content visit http://group.bmj.com/group/rights-licensing/permissions.

BMJ Case Report Fellows may re-use this article for personal use and teaching without any further permission.

Become a Fellow of BMJ Case Reports today and you can:

- Submit as many cases as you like

- Enjoy fast sympathetic peer review and rapid publication of accepted articles

- Access all the published articles

- Re-use any of the published material for personal use and teaching without further permission

For information on Institutional Fellowships contact consortiasales@bmjgroup.com

Visit casereports.bmi.com for more articles like this and to become a Fellow 